\title{
STUDI KEBERHASILAN PENGELOLAAN OBJEK WISATA TAMAN TEBING BREKSI BERBASIS COMMUNITY BASED TOURISM (CBT) OLEH MASYARAKAT DESA SAMBIREJO, KABUPATEN SLEMAN
}

\author{
Maria Gratia Plena Mervelito1), Parino Rahardjo ${ }^{21}$, Suryono Herlambang ${ }^{3)}$ \\ 1)Program Studi S1 PWK, Fakultas Teknik, Universitas Tarumanagara, margrat14@gmail.com \\ 2)Program Studi S1 PWK, Fakultas Teknik, Universitas Tarumanagara, parinor19@gmail.com \\ 3)Program Studi S1 PWK, Fakultas Teknik, Universitas Tarumanagara, s.herlambang@gmail.com
}

\begin{abstract}
Abstrak
Saat ini, sektor pariwisata merupakan sektor yang cukup potensial untuk dikembangkan di Indonesia, karena dianggap membawa dampak positif sebagai penggerak aktivitas perekonomian di negara ini. Selain itu, berkembangnya objek-objek wisata diharapkan juga mampu meningkatkan perekonomian masyarakat di sekitarnya dan mengedukasi masyarakat untuk dapat mengembangkan daerahnya sendiri. Taman Tebing Breksi di Kabupaten Sleman, Yogyakarta adalah salah satu objek yang memiliki potensi wisata yang berhasil dikelola dengan menggunakan konsep Community Based Tourism (CBT) oleh masyarakat Desa Sambirejo. Belum diketahuinya faktor-faktor yang menentukan keberhasilan dalam pengelolaan merupakan permasalahan yang terjadi dalam pengelolaan objek wisata Taman Tebing Breksi. Tujuan utama dari penelitian ini adalah untuk menganalisis faktor-faktor keberhasilan pengelolaan objek wisata Taman Tebing Breksi yang menerapkan konsep Community Based Tourism (CBT). Konsep CBT merupakan salah satu cara untuk menciptakan industri pariwisata berkelanjutan di suatu daerah, dimana partisipasi masyarakat setempat dibutuhkan dalam mengembangkan objek wisata sehingga pengelolaanya berhasil. Penelitian ini merupakan penelitian deskriptif dengan kombinasi pendekatan kualitatif dan kuantitatif. Pengumpulan data kuantitatif dilakukan dengan melakukan survey lapangan ke lokasi wisata dan wawancara mendalam (in-depth interview) dengan pihak terkait, sedangkan untuk pengumpulan data kualitatif dilakukan dengan pengisian kuesioner oleh pengunjung. Penelitian ini mendapatkan hasil berupa faktorfaktor yang mempengaruhi keberhasilan dalam pengelolaan objek wisata Taman Tebing Breksi.
\end{abstract}

Kata kunci: Kriteria Keberhasilan; Pengelolaan Pariwisata Berbasis Masyarakat; Taman Tebing Breksi; Wisata Geopark

\begin{abstract}
At present, the tourism sector is a sector that is quite potential to be developed in Indonesia, because it is considered to have a positive impact as a driver of economic activity in this country. In addition, the development of tourism objects is also expected to be able to improve the economy of the surrounding community and educate the public to be able to develop their own area. Taman Tebing Breksi in Sleman Regency, Yogyakarta is one of the objects that has a tourism potential that was successfully managed by using the concept of Community Based Tourism (CBT) by the people of Sambirejo Village. Not yet known the factors that determine success in management are problems that occur in the management of the Taman Tebing Breksi. The main objective of this research is to analyze the factors of success in managing the Taman Tebing Breksi tourism object that applies the concept of Community Based Tourism (CBT). The concept of CBT is one way to create a sustainable tourism industry in an area, where local community participation is needed in developing tourism objects so that the management is successful. This research is a descriptive study with a combination of qualitative and quantitative approaches. Quantitative data collection is done by conducting field surveys to tourist sites and in-depth interviews with related
\end{abstract}


parties, while for collecting qualitative data is done by filling out questionnaires by visitors. From this study the results will be obtained in the form of factors that influence the success in the management of Breksi Cliff Park attractions.

Keywords: Breksi Cliff Park; Community Based Tourism Management; Geopark Tourism; Success Criteria

\section{PENDAHULUAN}

\section{Latar Belakang}

Saat ini, pariwisata merupakan bidang yang potensial untuk dikembangkan karena pariwisata dianggap membawa dampak positif sebagai motor aktivitas perekonomian di Indonesia (Jannah, 2018). Wilayah yang memiliki potensi wisata dapat menghidupkan kembali kegiatan perekonomian masyarakat sekitar dengan munculnya usaha kecil hingga menengah, sehingga akan mengurangi pengangguran, meningkatkan pendapatan masyarakat, dan meningkatkan pendapatan lokal yang akan digunakan kembali oleh pemerintah untuk melakukan pembangunan dan kesejateraan masyarakat di daerah tersebut (Nandi dan Nissa, 2018). Berbagai program dibuat oleh pemerintah dan kementerian terkait untuk mengembangkan setiap objek wisata potensial di setiap daerah. Salah satu program yang dibuat oleh pemerintah mengacu pada konsep Community-Based Tourism atau Pariwisata Berbasis Masyarakat.

Menurut Blackstock (2005) Community-Based Tourism (CBT) bisa menjadi salah satu cara untuk menciptakan suatu industri pariwisata secara berkelanjutan. Di dalam Community Based Tourism ini masyarakat lokal berperan utama dalam mengembangkan desa wisata dengan kemampuan masyarakat lokal sendiri, pemberdayaan, keberlanjutan, konservasi dan peningkatan budaya untuk meningkatkan mata pencaharian penduduk (Putri dan Manaf, 2013). Namun secara keseluruhan, CBT dapat diidentifikasi sebagai strategi untuk pengembangan masyarakat melalui kemandirian, pemberdayaan, keberlanjutan dan konservasi dan peningkatan budaya untuk mata pencaharian yang lebih baik dalam masyarakat (Giampiccoli dan Kalis, 2012).

Taman Tebing Breksi merupakan salah satu objek wisata yang pengelolaannya berbasis CBT (Community Based Tourism) yang berlokasi di Desa Sambirejo, Kecamatan Prambanan, Kabupaten Sleman, Daerah Istimewa Yogyakarta. Taman Breksi yang saat ini memiliki luas $\pm 8,5$ $\mathrm{Ha}$ ini awalnya merupakan sebuah bekas tambang yang terbengkalai karena ditutupnya area tambang setelah diketahui bahwa bukit tersebut adalah sebuah peninggalan geologi.

Menurut sumber Tribun Jogja (2017) menginformasikan bahwa di tahun ke-2 sejak peresmiannya pada tahun 2015, objek wisata Taman Breksi sudah memiliki pendapatan tahunan sebesar 150 juta rupiah dengan kunjungan tertinggi pada 25 Desember 2017 sebanyak 7.550 pengunjung. Hal ini membuat Taman Tebing Breksi mendapatkan peringkat 1 Anugrah Pesona Indonesia Kategori Objek Wisata Baru Terpopuler Kementerian Pariwisata 2017. Sedangkan sumber Radar Yogya (2019) menyatakan pada tahun 2019, berdasarkan rekap data terakhir, Taman Tebing Breksi dipadati pengunjung pada masa Libur Lebaran dengan kunjungan tertinggi pada 7 Juni 2019 dengan pengunjung sebanyak \pm 10.000 pengunjung. Dua bulan sebelumnya, berdasarkan Tribun Jogja (2019) tepat pada tanggal 2 April 2019, Pokdarwis pengembang Taman Tebing Breksi, yakni Pokdarwis Tlatar Seneng mendapatkan penghargaan sebagai Pokdarwis Terbaik Se-DIY.

\section{Rumusan Permasalahan}

Keberhasilan pengelolaan yang diterapkan pada objek wisata Taman Tebing Breksi menimbulkan sebuah pertanyaan besar terkait faktor-faktor yang menentukan keberhasilan 
pengelolaan berbasis CBT ini. Pertanyaan tersebut selanjutnya dikaji dalam sebuah penelitian yang terkait dengan penerapan konsep Community Based-Tourism. Berkembangnya dan dicapainya keberhasilan pengelolaan objek wisata Taman Tebing Breksi ini nantinya mampu untuk meningkatkan perlahan kesejahteraan masyarakat sekitarnya terutama masyarakat Desa Sambirejo. Selain itu, bagaimana dampak dari berkembangnya objek wisata Taman Tebing Breksi ini terhadap budaya dan lingkungan sekitarnya perlu diperhatikan lagi oleh pengelola sehingga Taman Tebing Breksi dapat menjadi salah satu objek wisata yang berkelanjutan.

\section{Tujuan}

Tujuan utama dari studi ini adalah menganalisis faktor-faktor yang mempengaruhi keberhasilan pengelolaan obyek wisata Taman Breksi dengan penerapan konsep Community Based Tourism.

\section{KAJIAN LITERATUR}

\section{Pariwisata}

Menurut Istilah pariwisata adalah suatu kegiatan wisata (tour), yaitu suatu aktivitas perubahan tempat tinggal sementara dari seseorang, di luar tempat tinggal sehari-hari dengan suatu alasan apapun selain bukan melakukan kegiatan yang bisa menghasilkan upah (Damanik dan Helmut, 2006). Menurut Inskeep (1991) dalam bukunya menyatakan bahwa terdapat komponenkomponen yang terdapat dalam sebuah objek wisata, antara lain: (1) Atraksi dan kegiatankegiatan wisata, yaitu berupa lingkungan alami, kebudayaan, keunikan suatu daerah dan kegiatan lain yang menarik minat wisatawan untuk mengunjungi sebuah objek wisata; (2) Akomodasi, seperti berbagai macam hotel dan jenis fasilitas lain untuk wisatawan bermalam selama kegiatan perjalanan wisata yang mereka lakukan; (3) Fasilitas dan pelayanan wisata, yaitu fasilitas perencanaan kawasan wisata, termasuk tour and travel operations atau pelayanan penyambutan wisatawan, misalnya restoran dan tempat makan, toko menjual kerajinan tangan, cinderamata, bank, tempat penukaran uang dan fasilitas pelayanan lainnya; (4) Fasilitas dan pelayanan transportasi, meliputi transportasi akses dari dan menuju kawasan wisata, transportasi internal di kawasan wisata; (5) Infrastruktur lain, seperti penyediaan air bersih, listrik, drainase, saluran air kotor, telekomunikasi seperti telepon, telegram, faksimili; (6) Elemen kelembagaan, yaitu kelembagaan yang diperlukan untuk membangun dan mengelola kegiatan wisata.

Yoeti (1996) menyatakan bahwa suatu objek wisata atau daya tarik wisata dapat menarik dikunjungi bila memenuhi syarat-syarat sebagai berikut: (1) Something to see, di tempat tersebut harus ada objek wisata dan atraksi wisata, yang berbeda dengan apa yang dimiliki oleh orang lain. Dengan perkataan lain, daerah itu harus mempunyai daya tarik khusus, di samping itu ia harus mempunyai pula atraksi wisata yang dapat dijadikan entertainments bila orang datang ke sana. (2) Something to do, di tempat tersebut setiap banyak yang dapat dilihat dan disaksikan, harus pula disediakan fasilitas rekreasi atau amusement dan tempat atau wahana yang bisa digunakan wisatawan untuk beraktivitas seperti olah raga, kesenian maupun kegiatan lain yang dapat membuat mereka betah tinggal lebih lama. (3) Something to buy, di tempat tersebut harus tersedia fasilitas untuk berbelanja (shopping), terutama barang-barang souvenir dan kerajinan rakyat sebagai oleh-oleh untuk dibawah pulang ke tempat asal masing-masing. Fasilitas untuk berbelanja ini tidak hanya menyediakan barang-barang yang dapat dibeli, tetapi harus tersedia sarana-sarana pembantu lain untuk lebih memperlancar seperti money changer, bank, kantor pos, dan lain-lainnya.

\section{Community Based Tourism (CBT)}

Pinel (2007) dalam studi Hadiwijoyo (2012) menggambarkan Community Based Tourism (CBT) sebagai model pengembangan pariwisata yang berasumsi bahwa pariwisata harus berangkat dari kesadaran nilai-nilai kebutuhan masyarakat sebagai upaya membangun pariwisata yang 
lebih bermanfaat bagi kebutuhan, inisiatif dan peluang masyarakat lokal. Yaman dan Mohd (2004) menjelaskan mengenai beberapa kunci pengaturan pariwisata dengan pendekatan Community Based Tourism diantara lain:

a. Adanya dukungan pemerintah, Community Based Tourism membutuhkan dukungan struktur yang multi institusional agar sukses dan berkelanjutan. Pendekatan Community Based Tourism berorientasi pada masyarakat yang mendukung pembagian keuntungan dan manfaat yang adil serta mendukung pemberantasan kemiskinan dengan mendorong pemerintah dan masyarakat untuk tetap menjaga sumber daya alam dan budaya. Pemerintah akan berfungsi sebagai fasilitator, coordinator atau badan penasehat SDM dan penguatan kelembagaan.

b. Partisipasi dari masyarakat, Community Based Tourism dideskripsikan sebagai variasi aktivitas yang meningkatkan dukungan yang lebih luas terhadap pembangunan ekonomi dan sosial masyarakat. Konservasi sumber daya juga dimaksudkan sebagai upaya melindungi dalam hal memperbaiki mata pencaharian masyarakat. Community Based Tourism secara umum bertujuan untuk penganekaragaman industri, peningkatan partisipasi yang lebih luas ini termasuk partisipasi dalam sektor informal, hak dan hubungan langsung dan tidak langsung dari sektor lainnya. Anggota masyarakat dengan kemampuan kewirausahaan dapat menentukan/membuat kontak bisnis dengan tour operator, travel agent untuk memulai bisnis baru. Dengan ini partisipasi dari stakeholder sangat diperlukan untuk pendekatan Community Based Tourism.

c. Pembagian keuntungan yang adil, dengan keuntungan yang diterima oleh masyarakat secara langsung yang memiliki usaha di sektor pariwisata tetapi juga keuntungan tidak langsung yang diterima dan dinikmati masyarakat dari kegiatan pariwisata jauh lebih luas antara lain berupa proyek pembangunan yang dibiayai dari hasil penerimaan pariwisata.

d. Penggunaan sumber daya lokal secara berkesinambungan, pariwisata sangat bergantung pada sumber daya alam dan budaya setempat. Dimana aset tersebut dimiliki dan dikelola oleh seluruh anggota masyarakat, baik secara individu maupun kelompok.

e. Penguatan institusi lokal, usaha pariwisata di daerah pedesaan sulit diatur oleh lembaga yang ada. Maka dari itu penting untuk melibatkan komite dengan anggota yang berasal dari masyarakat. Tujuan utamanya adalah mengatur hubungan antar penduduk, sumber daya, dan pengunjung. Hal ini sangat membutuhkan perkembangan kelembagaan yang ada di suatu desa tersebut, yang paling baik adalah terbentuknya lembaga dengan pimpinan yang dapat diterima semua anggota masyarakat. Penguatan kelembagaan dapat dilakukan melalui pelatihan dan pengembangan individu dengan keterampilan kerjanya.

Karacaoğlu dan Birdir (2017) menyatakan terdapat 10 faktor sukses keberhasilan dari pengelolaan berbasis Community Based Tourism. Faktor-faktor keberhasilan pengelolaan berbasis Community Based Tourism, ditunjukkan pada Tabel 1.

Tabel 1. Faktor-Faktor Keberhasilan Pengelolaan Berbasis Community Based Tourism

\begin{tabular}{|c|c|c|}
\hline No & Faktor-Faktor & Indikator \\
\hline 1 & Kepuasan wisatawan & Kepuasan wisatawan dari berbagai aspek \\
\hline 2 & $\begin{array}{l}\text { Hubungan antar masyarakat satu } \\
\text { sama lain }\end{array}$ & $\begin{array}{l}\text { Berdasarkan pertemanan individu dan jaringan keluarga } \\
\text { anggota masyarakat }\end{array}$ \\
\hline 3 & Keaslian lokal & Identitas budaya otentik dan warisan budaya yang unik \\
\hline 4 & Keunikan lokal & Tercipta perbedaan dengan objek wisata lain \\
\hline 5 & Kepemilikan lokal & $\begin{array}{l}\text { Masyarakat sebagai pemilik sumber daya budaya dan } \\
\text { alam }\end{array}$ \\
\hline 6 & Kepemimpinan lokal & $\begin{array}{l}\text { Pemimpin lokal mengelola, mengarahkan \& } \\
\text { membangun hubungan antara masyarakat dan } \\
\text { stakeholders }\end{array}$ \\
\hline
\end{tabular}




\begin{tabular}{lll}
\hline No & \multicolumn{1}{c}{ Faktor-Faktor } & \multicolumn{1}{c}{ Indikator } \\
\hline 7 & Dukungan masyarakat & $\begin{array}{l}\text { Dukungan masyarakat dalam tahap perencanaan, } \\
\text { perangkulan, implementasi dan evaluasi keberhasilan } \\
\text { CBT }\end{array}$ \\
\hline \multirow{2}{*}{$\begin{array}{l}\text { Skala pengembangan pariwisata } \\
\text { 10 }\end{array}$} & Kerjasama antar stakeholders & $\begin{array}{l}\text { Pengembangan dan pengelolaan pariwisata sesuai } \\
\text { dengan prioritas, tuntutan, dan sumber daya } \\
\text { masyarakat }\end{array}$ \\
\hline stakeholders & Masyarakat dan stakeholders berkolaborasi \\
\hline
\end{tabular}

Sumber : Karacaoğlu dan Birdir, 2017

\section{METODE}

Metode penelitian yang digunakan untuk dapat mencapai tujuan dari studi ini adalah metode penelitian deskriptif dengan kombinasi pendekatan kualitatif dan kuantitatif. Penelitian deskriptif adalah penelitian yang memberikan gambaran secara detail suatu fenomena atau masalah dengan pendekatan kualitatif, artinya data penelitian dikumpulkan dengan cara studi literatur, ataupun wawancara yang mendalam dengan pihak-pihak terkait.

\section{Obyek Penelitian dan Pengumpulan Data}

Studi ini mengambil obyek penelitian tentang pengelolaan obyek wisata Taman Breksi di Desa Sambirejo, Kecamatan Prambanan, Kabupaten Sleman, Daerah Istimewa Yogyakarta. Objek wisata Tebing Breksi merupakan salah satu daya tarik wisata yang terdapat di Desa Sambirejo, Kecamatan Prambanan, Kabupaten Sleman, Daerah Istimewa Yogyakarta. Luas objek wisata Tebing Breksi yang sudah dikembangkan saat ini, yaitu seluas $\pm 8,5 \mathrm{Ha}$. Objek wisata Tebing Breksi dikelola oleh Lowo ljo sebagai pengelola khusus Tebing Breksi.

a. Utara : Dusun Kikis

b. Timur : Dusun Kikis

c. Selatan : Dusun Nglengkong

d. Barat : Dusun Nglengkong

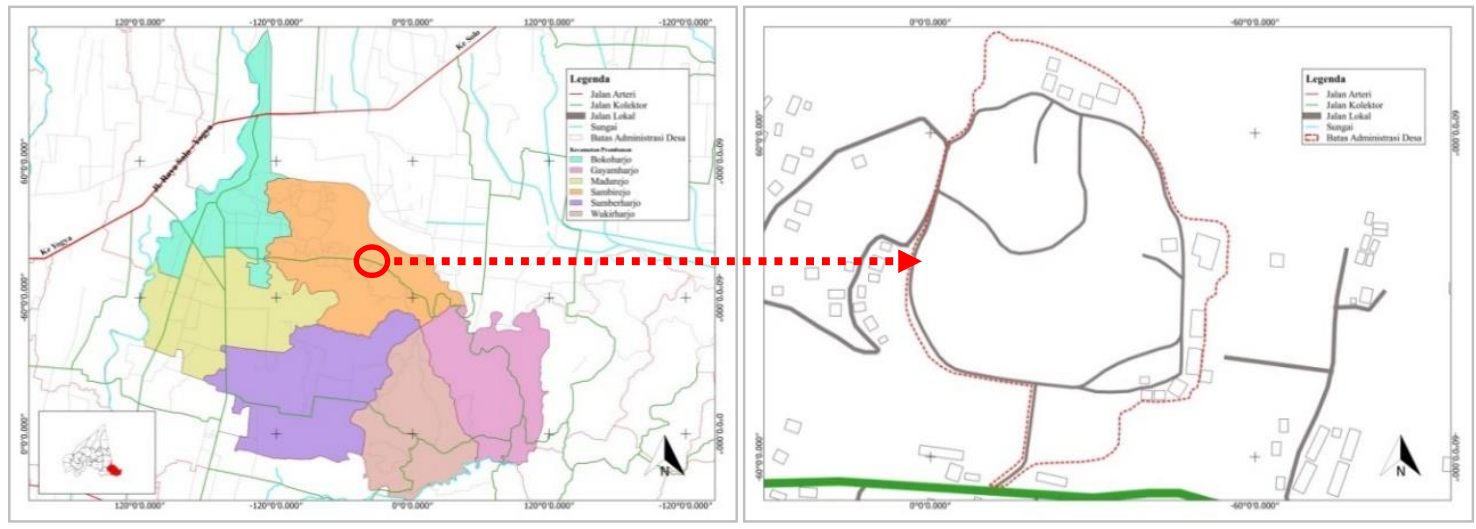

Gambar 1. Kecamatan Prambanan (kiri) dan Lokasi Objek Wisata (kanan)

Sumber : Hasil Olahan Penulis, 2020 

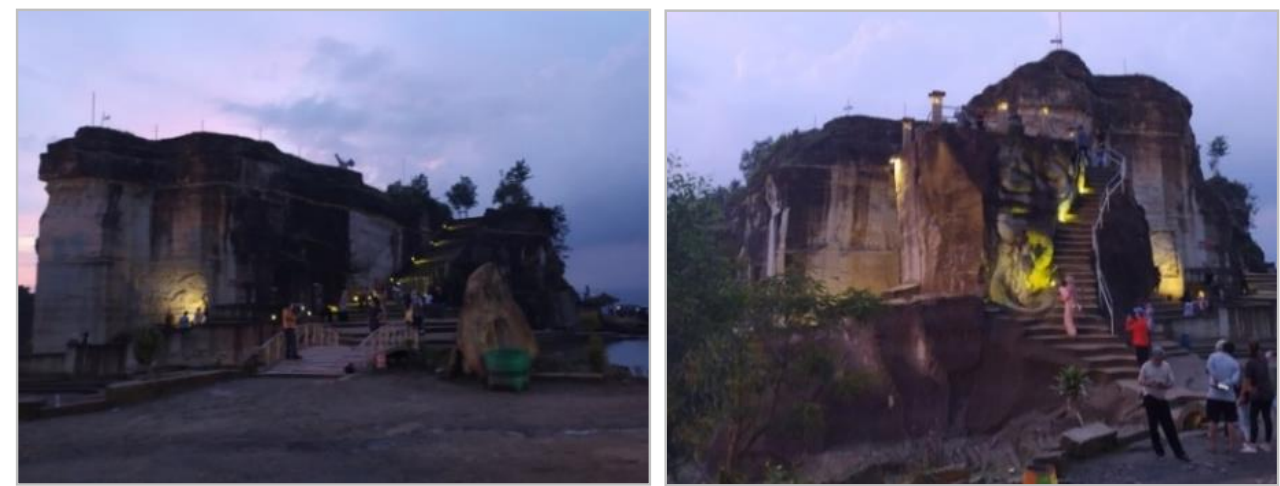

Gambar 2. Objek Wisata Tebing Breksi, Tebing Besar (kiri) dan Tebing Kecil (kanan) Sumber : Survey Lapangan, 2019

Pengumpulan data kualitatif dilakukan dengan cara melakukan observasi dan wawancara dengan teknik yang digunakan adalah in-depth interview yang ditujukan kepada narasumber yang memiliki keterkaitan dengan pengelolaan objek wisata Taman Breksi. Sedangkan, pengumpulan data kuantitatif dilakukan dengan penyebaran kuesioner pengunjung.

\section{Analisis Data}

Analisis lokasi merupakan analisis yang dilakukan untuk melihat pengaruh dari lokasi, aksesibilitas, penggunaan lahan eksisting, aktivitas sekitar kawasan, serta proximity yang mendukung keberadaan objek studi pada lokasi. Analisis pengelolaan berbasis CBT (Community Based Tourism), yaitu analisis yang bertujuan untuk mengetahui implementasi dari konsep CBT yang dilakukan pada pengembangan objek studi dengan membandingkannya dengan teori-teori mengenai CBT pada tinjauan teori. Analisis akan dilakukan dengan menggunakan data yang didapatkan dari hasil wawancara, jumlah kunjungan wisata, serta pendapatan. Analisis persepsi dan preferensi pengunjung yang bertujuan untuk mengetahui penilaian, pandangan, dan harapan wisatawan serta stakeholder terhadap kondisi kawasan dan pengelolaan yang sudah dilakukan di objek wisata Taman Breksi serta kepuasan pengunjung terhadap Taman Breksi. Pengolahan data pada analisis ini akan menggunakan metode IPA dan CSI. Analisis faktor keberhasilan pengelolaan objek wisata Taman Breksi berbasis CBT, yaitu analisis yang bertujuan untuk mengetahui faktor-faktor apa saja yang mempengaruhi keberhasilan pengelolaan objek wisata Taman Breksi yang dilakukan oleh masyarakat Desa Sambirejo yang berbasis CBT (Community Based Tourism).

\section{DISKUSI DAN HASIL}

\section{Analisis Lokasi}

Berdasarkan Gambar 3 yang memuat peta aksesibilitas dan peta proximity, objek wisata Taman Tebing Breksi dapat diakses dengan mudah karena lokasinya yang berada tidak jauh dari Jalan Provinsi yang menghubungkan Provinsi Daerah Istimewa Yogyakarta dan Provinsi Jawa Tengah, serta dikelilingi oleh beberapa objek wisata yang tersebar di sekitarnya. Jaraknya yang tidak jauh dari pusat Kota Jogja sebagai pusat destinasi wisata memungkinkan bagi para wisatawan yang sedang berlibur di Kota Jogja untuk dapat berkunjung ke Taman Breksi. Selain itu, kedekatan lokasi objek wisata Taman Breksi dengan objek wisata di sekitarnya ini dimanfaatkan oleh pengelola objek wisata Taman Breksi untuk membuat paket wisata keliling bekerja sama dengan Koperasi Jeep Shiva Plateu. Dengan membuat paket wisata ini, pengelola berharap tidak hanya Taman Breksi saja yang dikenal oleh wisatawan tetapi juga objek wisata lain di Desa Sambirejo ataupun desa lainnya, sehingga objek wisata lainnya juga ikut terbantu baik dalam hal promosi ataupun pendapatan. 


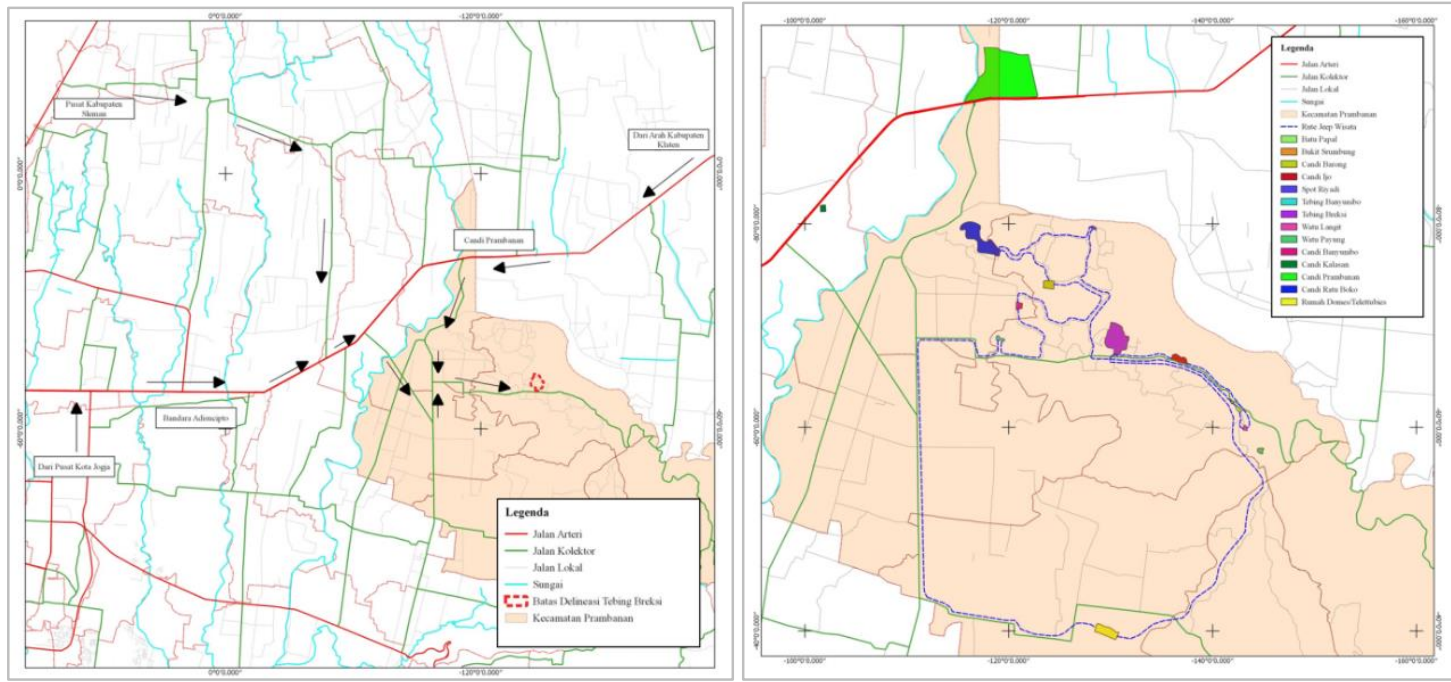

Gambar 3. Peta Aksesibilitas (kiri) dan Peta Proximity (kanan)

Sumber : Hasil Olahan Penulis

\section{Analisis Pengelolaan Berbasis Community Based Tourism (CBT)}

Adanya dukungan pemerintah

Keberadaan objek wisata Taman Breksi hingga saat ini tak lepas dari dukungan pemerintah setempat dan juga Pemerintah Daerah. Hal ini dapat dilihat dari beberapa hal, yakni adanya Peraturan atau Surat Keputusan (SK) yang mendukung berkembangnya objek wisata Taman Breksi, serta bantuan dari beberapa Kementerian terkait pengembangan objek wisata Taman Breksi baik secara tunai maupun non-tunai. Selain bantuan dari Pemerintah, terdapat pula beberapa bantuan dari swasta dan juga komunitas.

\section{Partisipasi masyarakat}

Pengelolaan objek wisata Taman Breksi tidak lepas dari partisipasi masyarakat sekitar, terutama warga Desa Sambirejo. Hal ini dapat dilihat dari banyaknya warga desa yang berpartisipasi dalam pengelolaan dan usaha yang ada di dalam Taman Breksi. Bentuk partisipasi tersebut dapat berupa partisipasi secara langsung maupun tidak langsung. Partisipasi masyarakat secara langsung pada objek wisata Taman Breksi dapat dilihat dari keberadaan pengelola, penjual, dan koperasi yang menjalankan tugasnya dan bekerja secara langsung di objek wisata Taman Breksi. Partisipasi masyarakat secara tidak langsung terlihat dengan adanya partisipasi warga desa dalam BUMDes dan Pokdarwis sebagai unit desa yang tidak terlepas dari proses pengembangan hingga pengelolaan objek wisata Taman Breksi.

\section{Pembagian keuntungan yang adil}

Pemasukan objek wisata Taman Breksi secara keseluruhan berasal dari beberapa sumber, yaitu karcis masuk dan tiket parkir, jeep wisata, taman kuliner, balkondes, Glam Camp, serta sewa tempat/amphitheater. Namun dari semua sumber pemasukan tersebut, tidak semuanya masuk ke dalam kas Pengelola Breksi. Hal ini ditunjukkan pada Gambar 4. 


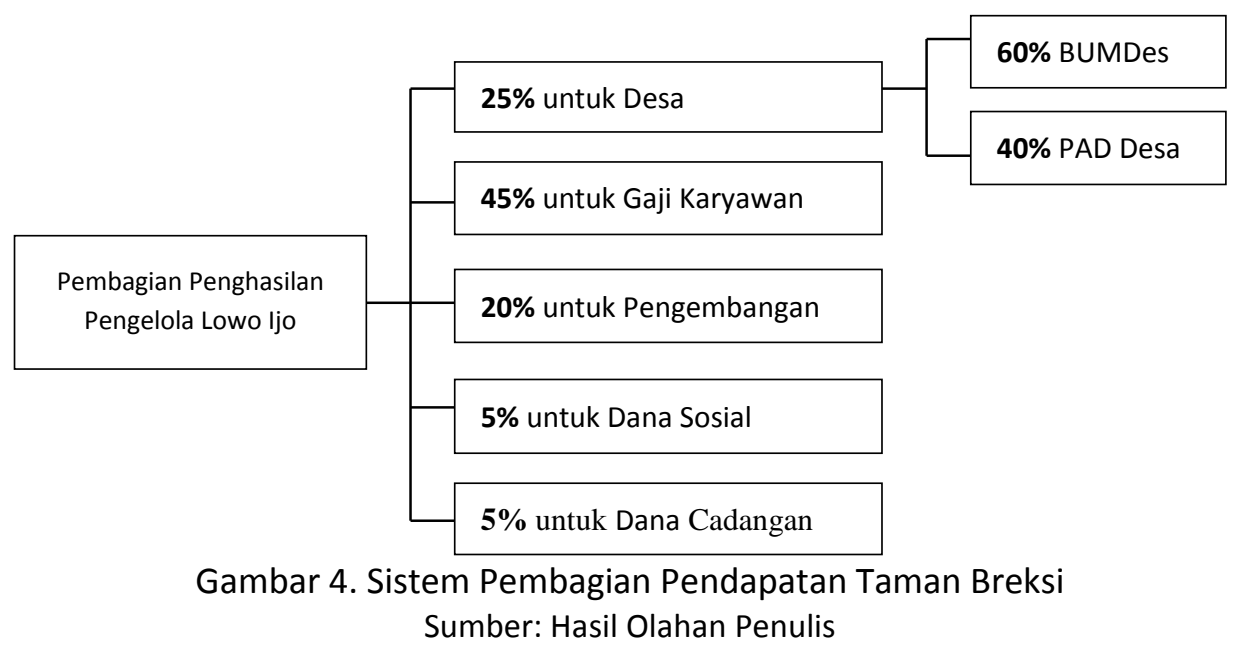

Dari persentase pembagian pendapatan tersebut terlihat bahwa keuntungan yang didapatkan dengan adanya Taman Breksi ini sudah terbagi merata dan adil, dimana setiap warga desa yang terjun dan terlibat dalam pengelolaan Taman Breksi mendapatkan keuntungan sesuai dengan perannya masing-masing.

\section{Penggunaan sumber daya lokal secara berkesinambungan}

Sejak dibukanya Taman Breksi sebagai objek wisata, masyarakat Desa Sambirejo mulai banyak berperan di dalamnya, baik sebagai karyawan pengelola, penjual, maupun unit-unit desa yang membantu secara tidak langsung. Jumlah masyarakat yang terlibat setiap tahunnya juga bertambah. Selain Taman Breksi, terdapat pula objek wisata alam lainnya di Desa Sambirejo yang banyak disinggahi pengunjung dengan adanya Jeep Tour. Hal ini menunjukkan bahwa masyarakat mulai merasa memiliki dan sama-sama menjaga kondisi alam yang ada di desanya. Seperti halnya yang dikatakan oleh salah satu mantan penambang yang menyatakan bahwa dengan dijadikannya Taman Breksi sebagai objek wisata, tebing tidak akan habis karena ditambang dan kondisi alam akan lebih terjaga sehingga anak cucu mereka nantinya dapat menikmati apa yang ada saat ini.

\section{Penguatan institusi lokal}

Keberadaan Pokdarwis dan BUMDes yang membantu membina masyarakat dan mengembangkan objek wisata Taman Breksi sangatlah bermanfaat. Dengan anggota yang seluruhnya warga Desa Sambirejo, kedua unit desa ini dapat menjaga hubungan antar penduduk dan memaksimalkan sumber daya yang ada. Pelatihan dan pembinaan kepada warga desa terus dilakukan sejak awal Taman Breksi mulai dikembangkan. Sehingga sampai saat ini sudah sebagian besar masyarakat Desa Sambirejo yang terlibat dalam pengelolaan Taman Breksi dan dapat menjadi pelaku wisata yang cukup baik.

\section{Analisis Persepsi dan Preferensi}

Analisis persepsi dilakukan dengan menggunakan metode IPA (Importance Performance Analysis) dan CSI (Customer Satisfaction Index) yang dihitung dengan skala likert dari hasil penyebaran kuesioner pengunjung. Dari hasil perhitungan CSI, didapatkan nilai kepuasan responden adalah sebesar $71.83 \%$, yang berarti bahwa responden sebagai sampel pengunjung objek wisata Taman Tebing Breksi merasa puas atas faktor-faktor kepuasan pengunjung yang terdapat dalam tabel tersebut.

Preferensi pengunjung didapatkan pula dari hasil penyebaran kuesioner terkait dengan kegiatan wisata baru yang perlu diadakan dan fasilitas yang perlu ditambahkan. Untuk kegiatan wisata baru yang perlu diadakan, dari hasil kuesioner yang diisi oleh responden pilihan paling banyak 
adalah penambahan kegiatan wisata kesenian daerah setempat dengan 50 orang responden memilih dari total 100 orang responden. Sedangkan untuk fasilitas yang perlu ditambahkan, pilihan yang paling banyak dipilih adalah pengaadaan ATM Center dengan 61 orang responden yang memilih dari total 100 orang responden.

\section{Analisis Faktor Keberhasilan Pengelolaan Berbasis CBT}

Berdasarkan hasil temuan dilapangan dengan menggunakan teknik survei maka hasil dan analisis faktor keberhasilan pengelolaan berbasis $C B T$ nya, di tunjukkan pada Tabel 2. yang oleh penulis kemudian diklasifikasikan menjadi 3, yaitu faktor yang terkait dengan konsep CBT, objek wisata, dan wisatawan.

Tabel 2. Analisis dan Klasifikasi Faktor-Faktor Keberhasilan Pengelolaan Berbasis Community Based Tourism Berdasarkan Hasil Temuan di Lapangan

\begin{tabular}{lcc}
\hline No Faktor-Faktor & Uraian Kondisi Eksisting & $\begin{array}{c}\text { Klasifikasi } \\
\text { Faktor } \\
\text { Keberhasilan }\end{array}$ \\
\hline
\end{tabular}

Dari hasil perhitungan dengan metode CSI (Customer

Satisfaction Index) didapatkan nilai kepuasan pengunjung secara keseluruhan sebesar $71,83 \%$ yang berarti

1 Kepuasan pengunjung merasa puas atas pengelolaan di objek wisata wisatawan Taman Tebing Breksi. Tingkat kepuasan pengunjung untuk setiap faktor berada pada rentang yang sama, yaitu $66 \%$ $80,99 \%$, yang menandakan pengunjung merasa puas dengan pengelolaan pada setiap faktor tersebut.

Sebagian besar warga terlibat dalam pengelolaan objek Hubungan wisata Taman Tebing Breksi dengan perannya masingantar masing di dalam pengelolaan tersebut. Adanya kerjasama

2 masyarakat satu sama lain dengan Koperasi Jeep Shiva Plateu menunjukkan bahwa Konsep CBT hubungan antar warga dengan daerah di luarnya juga sangat baik dan bersama-sama berusaha memajukan dan mengembangkan daerahnya.

Hingga saat ini belum ada atraksi budaya yang disajikan

3 Keaslian lokal secara rutin di objek wisata Taman Tebing Breksi, hal ini dikarenakan pengelola belum memiliki cukup dana untuk

Objek Wisata membiayai pertunjukkan bila diadakan secara rutin.

\section{Adanya tebing yang merupakan bekas tambang setinggi 30} meter yang ternyata merupakan peninggalan geologi dari gunung api purba yang tidak terdapat di objek wisata

4 Keunikan lokal lainnya serta memiliki nilai edukasi yang cukup tinggi. Selain itu, lokasi objek wisata yang berada di lokasi yang tinggi juga menarik minat pengunjung karena pengunjung akan dimanjakan dengan pemandangan alam Yogyakarta. Setiap tahunnya semakin banyak warga desa yang ingin bekerja di objek wisata ini, yang menunjukkan adanya rasa memiliki warga Desa Sambirejo akan keberadaan objek wisata tersebut karena adanya keinginan untuk dapat terus lokal mengembangkan dan menjaga objek wisata Taman Tebing Breksi. Dengan adanya rasa memiliki tersebut, masyarakat Desa Sambirejo akan semakin berusaha untuk bisa menjaga kelestariannya dan mengembangkannya demi kesejahteraan bersama masyarakat Desa Sambirejo.

Keberadaan Pemerintah Desa Sambirejo, BUMDes, 


\begin{tabular}{|c|c|c|c|}
\hline & & $\begin{array}{l}\text { dapat diarahkan dengan baik dan mendapatkan pembinaan } \\
\text { yang baik dalam meningkatkan kemampuannya sebagai } \\
\text { pelaku wisata dan menjaga hubungan satu sama lainnya. }\end{array}$ & \\
\hline 7 & $\begin{array}{l}\text { Dukungan } \\
\text { masyarakat }\end{array}$ & $\begin{array}{l}\text { Dukungan masyarakat yang terus meningkat terlihat seiring } \\
\text { dengan mulai berjalannya pengelolaan terhadap objek } \\
\text { wisata Taman Tebing Breksi dimana banyak masyarakat } \\
\text { desa yang mulai terlibat aktif dalam pengelolaan sebagai } \\
\text { karyawan kantor pengelola. Hal ini menunjukkan bahwa } \\
\text { keberadaan dan keberlangsungan objek wisata ini sudah } \\
\text { sangat berpengaruh bagi desanya, sehingga mereka } \\
\text { bersama-sama berusaha untuk menjaga dan terus } \\
\text { mengembangkannya. }\end{array}$ & Konsep CBT \\
\hline 8 & $\begin{array}{l}\text { Skala } \\
\text { pengembangan } \\
\text { pariwisata }\end{array}$ & $\begin{array}{l}\text { Gubernur ingin peninggalan geologi tersebut dijaga dan } \\
\text { dijadikan objek wisata guna meningkatkan kesejahteraan } \\
\text { masyarakat Desa Sambirejo, terutama mantan pekerja } \\
\text { tambang yang kehilangan pekerjaan karena ditutupnya } \\
\text { tambang. Dinas Pariwisata Provinsi Yogyakarta } \\
\text { menyarankan supaya objek wisata dikelola dengan sistem } \\
\text { Community Based Tourism (CBT) dengan meminta adanya } \\
\text { pembentukan Pokdarwis untuk membina masyarakat. }\end{array}$ & Objek Wisata \\
\hline 9 & $\begin{array}{l}\text { Kerjasama } \\
\text { antar } \\
\text { stakeholders }\end{array}$ & $\begin{array}{l}\text { Pengelolaan objek wisata Taman Tebing Breksi melibatkan } \\
\text { banyak stakeholders di dalamnya yang memiliki perannya } \\
\text { masing-masing dalam proses pengelolaan sehingga } \\
\text { pengelolaan dapat berjalan dengan baik. }\end{array}$ & Konsep CBT \\
\hline 10 & $\begin{array}{l}\text { Dukungan } \\
\text { eksternal dari } \\
\text { stakeholders }\end{array}$ & $\begin{array}{l}\text { Dukungan eksternal dari stakeholders juga banyak } \\
\text { didapatkan oleh objek wisata Taman Tebing Breksi sejak } \\
\text { awal pengembangan hingga pengelolaannya. Seluruh } \\
\text { dukungan yang didapatkan oleh objek wisata Taman Tebing } \\
\text { Breksi kini sangat bermanfaat dan menjadikan objek wisata } \\
\text { Taman Tebing Breksi berkembang seperti saat ini. }\end{array}$ & Konsep CBT \\
\hline
\end{tabular}

Sumber: Hasil Studi Penulis, 2020

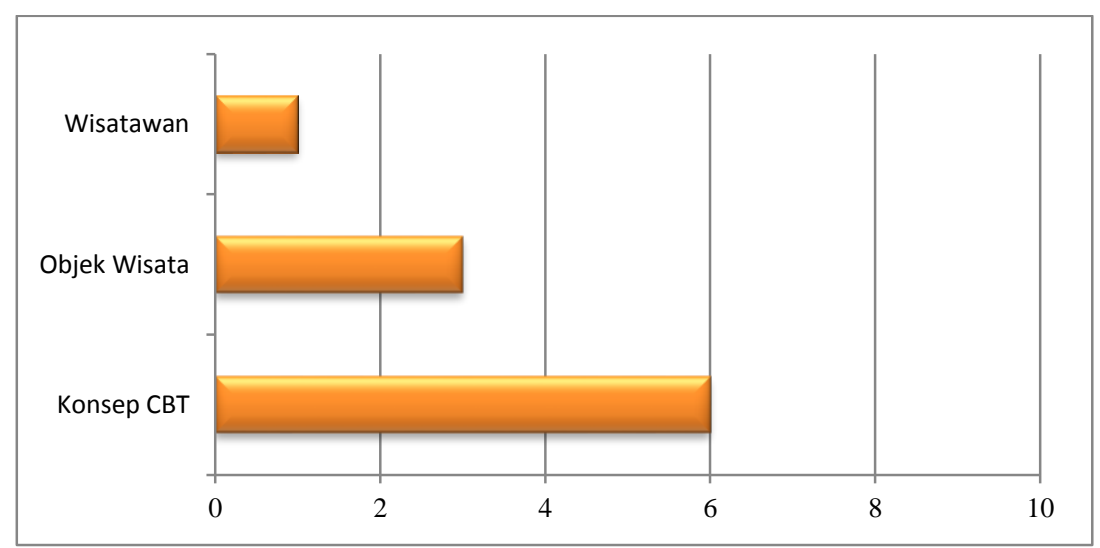

Gambar 5. Grafik Jumlah Klasifikasi Faktor Keberhasilan Sumber: Hasil Olahan Penulis

Dari hasil klasifikasi faktor-faktor keberhasilan pengelolaan CBT, kemudian setiap klasifikasi dimasukkan ke dalam grafik di atas dan didapatkan hasil klasifikasi terbanyak adalah faktorfaktor yang terkait dengan konsep CBT sebanyak 6 faktor. Lalu diikuti oleh klasifikasi yang terkait dengan objek wisata sebanyak 3 faktor, dan klasfikasi yang terkait dengan wisatawan sebanyak 1 faktor. Hal ini menunjukkan bahwa 6 faktor yang terkait dengan konsep CBT ini merupakan 6 
faktor yang terpenting dari 10 faktor yang ada dalam menjalankan pengelolaan objek wisata yang berbasis CBT. Tabel 3 berikut merupakan faktor-faktor keberhasilan yang telah diklasifikasikan berdasarkan analisis yang telah dijabarkan di atas.

Tabel 3. Faktor-Faktor Keberhasilan Pengelolaan berdasarkan Klasifikasi

\begin{tabular}{|c|c|c|}
\hline Konsep CBT & Objek Wisata & Wisatawan \\
\hline $\begin{array}{l}\text { Hubungan antar masyarakat satu } \\
\text { sama lain }\end{array}$ & Keaslian lokal & Kepuasan wisatawan \\
\hline Kepemilikan lokal & Keunikan lokal & \\
\hline Kepemimpinan lokal & Skala pengembangan pariwisata & \\
\hline \multicolumn{3}{|l|}{ Dukungan masyarakat } \\
\hline \multicolumn{3}{|l|}{ Kerjasama antar stakeholders } \\
\hline $\begin{array}{l}\text { Dukungan eksternal dari } \\
\text { stakeholders }\end{array}$ & & \\
\hline
\end{tabular}

Sumber: Hasil Studi Penulis, 2020

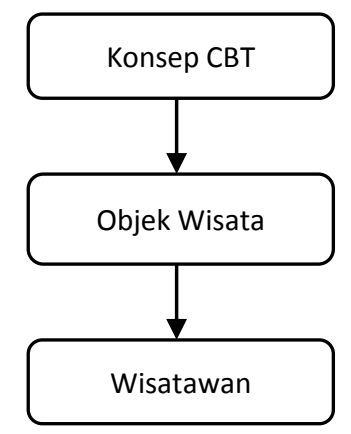

Gambar 6. Skema Klasifikasi Faktor Keberhasilan Sumber: Hasil olahan penulis, 2020

Dari hasil klasifikasi di atas, maka didapatkan hubungan seperti pada skema di atas terhadap objek wisata Taman Tebing Breksi. Dimana konsep CBT yang diterapkan di objek wisata Taman Tebing Breksi menjadi dasar dari pengelolaan yang dilakukan oleh stakeholders setempat yang berbasis masyarakat dan mempengaruhi keberlangsungan objek wisata Taman Tebing Breksi itu sendiri. Objek wisata Taman Tebing Breksi dikembangkan dan dikelola sedemikian rupa dari hasil penerapan konsep CBT. Dan hasil dari pengembangan dan pengelolaan inilah yang nantinya akan mempengaruhi kepuasan para wisatawan yang datang berkunjung.

Dari faktor-faktor yang masuk ke dalam klasifikasi konsep CBT di atas, penulis kemudian menyusun prioritas dari ke-6 faktor tersebut berdasarkan skala kepentingan sebagai berikut:

a. Kepemimpinan lokal

b. Dukungan eksternal dari stakeholders

c. Kerjasama antar stakeholders

d. Dukungan masyarakat

e. Hubungan antar masyarakat satu sama lain

f. Kepemilikan lokal

Kepemimpinan lokal menjadi prioritas pertama dalam pengelolaan CBT karena keberadaan stakeholders yang terkait adalah hal terpenting untuk memulai sebuah pengelolaan yang berbasis masyarakat. Seperti halnya yang dilakukan pada objek wisata Taman Tebing Breksi, saat awal pengembangan dibentuk Pokdarwis sebagai stakeholder yang bertanggung jawab untuk merangkul warga desa dan menciptakan kesadaran akan wisata. Setelah terbentuk stakeholder yang bertanggung jawab atas objek wisata tersebut, dukungan eksternal dari stakeholder, seperti Dinas Pariwisata setempat dan Pemerintah Daerah setempat akan memberikan 
dukungan pada objek wisata tersebut, baik berupa dukungan dalam bentuk Surat Keputusan atau dukungan berupa fasilitas dan sebagainya. Setelah itu, dijalinlah kerjasama antar stakeholder yang terkait dengan pengelolaan objek wisata, seperti pada pengelolaan objek wisata Taman Tebing Breksi dimana BUMDes, Pokdarwis, dan Pengelola bekerja sama untuk menjalankan pengelolaan dengan perannya masing-masing. Stakeholders yang berhasil menjalannkan perannya akan mendapatkan dukungan dari masyarakat dalam mengembangkan dan mengelola objek wisata dan hubungan antar masyarakat kemudian akan terjalin dengan baik satu sama lain. Setelah beberapa waktu dan pengelolaan berlangsung semakin baik, objek wisata Taman Tebing Breksi semakin mendapatkan dukungan dari warga Desa Sambirejo dan bahkan banyak warga desa yang tertarik bekerja sebagai karyawan pengelola di objek wisata Taman Tebing Breksi, sehingga hubungan antar masyarakat juga terjalin dengan baik. Dengan hubungan yang terjalin dengan baik, akan timbul rasa memiliki bersama akan objek wisata tersebut dan keinginan untuk dapat mengelolanya dengan baik demi kesejahteraan bersama. Pandangan ini juga dikemukaan oleh Dinas Pariwisata Provinsi yang melihat bahwa warga Desa Sambirejo sudah merasa sama-sama memiliki objek wisata Taman Tebing Breksi dan bersamasama berusaha terus mengembangkannya demi kesejahteraan bersama warga Desa Sambirejo, dan bahkan desaa-desa sekitarnya.

\section{KESIMPULAN DAN SARAN}

\section{Kesimpulan}

Dari hasil penelitian yang telah dilakukan terkait dengan studi keberhasilan terhadap objek wisata Taman Tebing Breksi, maka didapatkan faktor-faktor yang mempengaruhi keberhasilan pengelolaan yang berbasis Community Based Tourism (CBT) pada objek wisata Taman Tebing Breksi. Dengan diketahuinya faktor-faktor tersebut, seperti faktor-faktor yang terkait dengan konsep CBT (Community Based Tourism) itu sendiri, faktor yang terkait dengan objek wisata, serta faktor yang terkait dengan wisatawan, hasil studi ini diharapkan dapat menjadi bahan rujukan untuk pengembangan objek wisata berbasis CBT (Community Based Tourism) di daerah lain di Indonesia.

Pengelolaan yang dilakukan pada objek wisata Taman Tebing Breksi sudah memenuhi aspekaspek pendekatan $\mathrm{CBT}$, yaitu dengan adanya dukungan pemerintah, terwujudnya partisipasi masyarakat, pembagian keuntungan yang adil untuk seluruh stakeholder dan masyarakat, penggunaan sumber daya lokal secara berkesinambungan, serta penguatan institusi lokal. Adapun dari hasil analisis faktor keberhasilan didapatkan faktor-faktor yang mempengaruhi keberhasilan pengelolaan objek wisata Taman Tebing Breksi, yaitu terdapatnya kepemimpinan lokal, adanya dukungan eksternal dari stakeholders, terjalinnya kerjasama antar stakeholders, adanya dukungan masyarakat, terjalinnya hubungan yang baik antar masyarakat satu sama lain, serta adanya kepemilikan lokal. Kepemimpinan lokal merupakan salah satu faktor yang menjadi prioritas utama dalam pengelolaan wisata berbasis CBT, karena stakeholder menjadi hal yang mendasar dan berperan sebagai "key person" dalam memulai sebuah pengelolaan berbasis CBT untuk meningkatkan kesadaran wisata masyarakat setempat.

\section{Saran}

Usaha untuk meningkatkan kualitas pengelolaan pada objek wisata Taman Tebing Breksi dapat dimulai dari faktor-faktor yang terkait dengan konsep CBT, seperti mempertahankan kepemimpinan lokal yang sudah ada, meningkatkan kerjasama antar stakeholders, meningkatkan dukungan masyarakat, meningkatkan hubungan antar masyarakat satu sama lain, memperkuat kepemilikan lokal, dan meningkatkan dukungan eksternal dari stakeholders, karena faktor-faktor tersebut merupakan dasar dari penerapan konsep CBT. Kemudian dapat dilanjutkan dengan meningkatkan faktor-faktor yang terkait dengan objek wisata, dan yang terakhir faktor-faktor yang terkait dengan wisatawan. 


\section{REFERENSI}

Alwi, T. (2017, December 28). Pengunjung Naik 3 Kali Lipat, Pendapatan Pengelola Tebing Breksi Yogyakarta Capai Rp 62 Juta. Retrieved from Tribun Jogja: https://jogja.tribunnews.com/2017/12/28/pengunjung-naik-3-kali-lipat-pendapatanpengelola-tebing-breksi-yogyakarta-capai-rp-62-juta

Blackstock, K. (2005). A Critical Look at Community Based Tourism. Community Development Journal Vol 40(1), 79-87.

Damanik, J \& Helmut F. W. (2006). Perencanaan Ekowisata: dari Teori ke Aplikasi. Yogyakarta: ANDI OFFSET.

Ermando, A. (2019, April 2). Pokdarwis Pengelola Tebing Breksi Jadi yang Terbaik Se-Yogyakarta. Giampiccoli, A. \& Kalis, J.H. (2012). Community-Based Tourism and Local Culture: The Case Of The Amampondo. PASOS. Revista de Turismo y Patrimonio Cultural. Vol. 10(1), 173-188.

Hadiwijoyo, S. S. (2012). Perencanaan Pariwisata Perdesaan Berbasis Masyarakat (Sebuah Pendekatan Konsep). Yogyakarta: Graha Ilmu.

Inskeep, E. (1991). Tourism planning: an integrated and sustainable development approach. Van Nostrand Reinhold.

Jannah, E.U., Muryani, C., \& Rindarjono, M.G. (2018). Community-Based Tourism Development at Gajah Mungkur Wonogiri Tourist Attraction. IOP Conf. Series: Earth and Environmental Science 145, 798-807.

Karacaoğlu, S., \& Birdir, K. (2017). Success Factors of Community Based Tourism (CBT) Perceived by Local Peoples: The Case of \% 100 Misia Project. International Rural Tourism and Development Journal 1(2). 53-61.

Nandi \& Nissa, A. (2016). The characteristics of edutourism at cilegon krakatau steel industrial area Heritage, Culture and Society: Research agenda and best practices in the hospitality and tourism industry. Proceedings of the 3rd International Hospitality and Tourism Conference, IHTC and 2nd International Seminar on Tourism 2016.

Putri, H. P. J. \& Manaf, A. (2013). Faktor-Faktor Keberhasilan Pengembangan Desa Wisata Di Dataran Tinggi Dieng. Jurnal Teknik PWK Volume 2(3).

Retrieved from Tribun Jogja: https://jogja.tribunnews.com/2019/04/02/pokdarwis-pengelolatebing-breksi-jadi-yang-terbaik-se-yogyakarta

Wawan, J. (2019, June 11). Pengunjung Tebing Breksi Meningkat. Retrieved from Radar Jogja:https://radarjogja.jawapos.com/2019/06/11/pengunjung-tebing-breksimeningkat

Yaman, A. R., \& Mohd, A. (2004). Community-based Ecotourism: New Proposition forSustainable Development and Environment Conservation in Malaysia. Journal of Applied Sciences IV(4), 583-589.

Yoeti, O. A. (1996). Pengantar Ilmu Pariwisata. Bandung: Angkasa Offset. 
